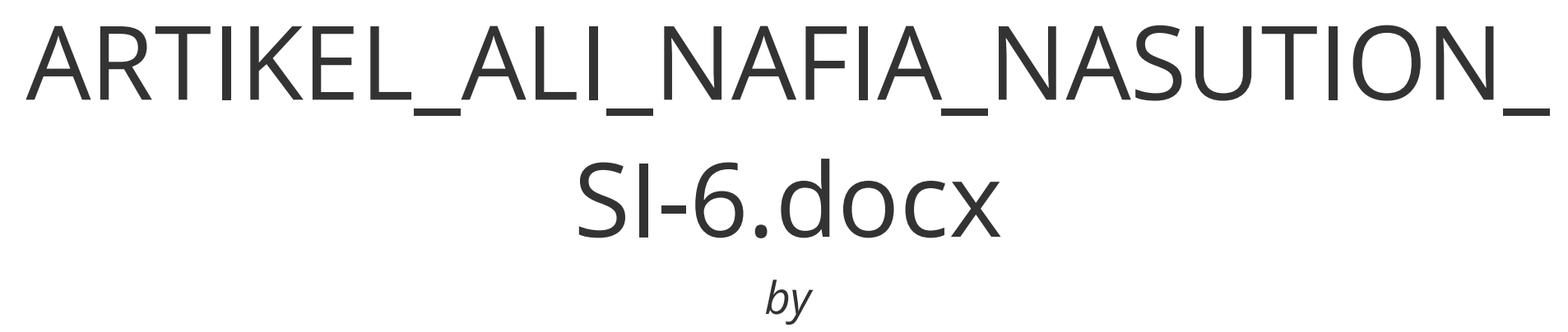

Submission date: 02-Jan-2022 03:37PM (UTC+0700)

Submission ID: 1736838587

File name: ARTIKEL_ALI_NAFIA_NASUTION_SI-6.docx (19.39K)

Word count: 2980

Character count: 19450 


\title{
MAKALAH ILMU KOMPUTER \\ PERBANDINGAN SISTEM OPERASI LINUX DENAGN \\ SISTEM OPERASI WINDOWS PADA SISTEM \\ INFORMASI MANAJEMEN
}

Dosen Pembimbing :

Dr Yahfizham, S.T MCs

ALI NAFIA NASUTION (0702212232)

Prodi Sistem Informasi, Fakultas Sains dan Teknolgi, UINSU

Jl. Lap. Golf, Kp. Tengah, Kec. Pancur Batu, Kabupaten Deli Serdang, Sumatera Utara 20353, Indonesia

TP.2021/2022

Mr.alinafia2016@gmail.com

\begin{abstract}
Abstrak
Kegiatan pengabdian masyarakat berbasis Windows 10 bertajuk "Instalasi Sistem Operasi" ini bertujuan untuk menginformasikan Asahan, mahasiswa MAN, tentang penginstalan Kerangka kerja Windows. Teknik yang digunakan dalam aksi ini ialah dengan mengamati ${ }_{3}$ cara lantas madrasah School melalui cara menyelidiki dan menganalisis permasalahan atau troubleshooting yang terjadi pada lab komputer di MAN Asahan School. Selain itu, sebagai pelaksana kegiatan pengabdian ini, informasi masalah lab komputer sekolah akan diberikan kepada tim pengajar melalui tanya jawab sekarang dengan master bersama karyawan bahwa bekerja pada ruang monitor madrasah. Perolehan upaya ini penting untuk siswa dapat memperbaiki komputer serta memecahkan masalah PC sekolah dan rumah tanpa memerlukan suka rela pembetulan PC.
\end{abstract}

Kata kunci: pendirian; kerangka kerja; Windows 10

\section{PRESENTASI}

Sistem operasi sendiri mempunyai füpsi dan tujuan yaitu kenyamanan atau kemudahan, Semua fungsi dan tujuan sistem operasi Sementara tujuan kita mempelajari sistem operasi sebenarnya agar kita dapat merancang atau membuat sendiri serta juga dapat mengembangkan sistem operasi yang telah ada pada saat ini yang mana yang harus kita gunakan pada komputer 
kita sesuai dengan tyjuan berbasis komputer keputusan memilih sistem operasi merupakan keputusan utama dan sangat penting karena merupakan konsep utama dan sangat mendasar saat teknik sistem operasi terpebut Setelah kita mempelajari fungsi dan tujuan sistem operasi komputer sekarang kita ${ }_{1}$ interface atau bisa di sebut juga dengan pembuatan program yaitu dimana system operøi sistem operasi mengambil alih dalam proses input yang rumit dan juga sinyal kendali agar be 1 kas atau juga bisa di sebut file-system mempunyai mekanisme proteksi dari sistem operasi. Menyediakan system communications / networking yang artinya pada pengaksesan semua dapat di akses atau digunaka 1 bersama (shared system). Mampu melakukan error detection yang artinya system operasi melakukan resource Sharing yang mana pemakai dapat berbagi sumberdaya. fasilitas security artinya sistem operasi mampu memberikan sebuah tanggapan yang menjelaskan Fasilitas accounting system dimana sistem operasi yang bagus sebuah kerangka kerja produk yang mampu menangani penggunaan peralatan dan program aplikasi, terkait erat dengan aktivitas PC saat ini. Strategi yang digunakan untuk pemilihan Windows ${ }_{2}$ orking Framework, khususnya Choice Emotionally supporting network (DSS) dengan teknik AHP dapat digunakan dalam pengambilan keputusan untuk masalah yang dialami dalam memilih kerangka kerja Windows (Kelviandy, 2014) (Susilo , 2016). .dengan memberikan aturan dan pilihan.

Banyaknya jenis framework kerja seperti Ms DOS, Windows 95, Windows 98, Windows XP, Linux, Mac da ${ }_{2}$ lain-lain yang sudah tersedia membuat penelitian ini mengambil contoh dari framework kerja Windows yang sangat diminati oleh pelanggan hari ini dengan melihat Windows 7, Windows 8 dan Windows. windows 10. Oleh karena itu, pengujian dilakukan untuk mengeksplorasi kerangka kerja windows yang tepat dan paling banyak diminta oleh pembeli, terutama di kalangan mahasiswa.

Mengingat fondasi, pengaturan pene ${ }_{2}^{2}$ tian, dan sebagian dari fokus penelitian, ulasan ini berarti bekerja dengan pilihan sistem kerja Windows yang sesuai dengan kebutuhan siswa dan siswa dengan melihat sorotan terkini dari masing-masing jenis. kerangka kerja Windows.

Peningkatan inovasi di Indonesia saat ini berkembang pesat. Masing ${ }_{3}$ masing sekolah berlomba-lomba untuk memberikan kantor yang terbaik kepada siswanya, termasuk dengan memberikan kantor yang memudahkan pengajar untuk memberikan materi ajar kepada siswanya. Salah satu penunjang sekolah di Indonesia adalah memberikan fasilitas penelitian PC kepada siswa untuk melengkapi proses belajar dan mengajar. PC adalah perangkat yang digunakan untuk menangani informasi sesuai sistem yang telah dibuat (Eska, 2018)

Seko $\sigma_{3}$ h MAN Kisaran ini telah menyelidiki di mana salah satu lab PC mereka tidak menyetujui sistem operasi Windows yang mereka gunakan selama ini, tentu saja, dengan berita seperti ini, kekhawatiran yang menggelitik tentang masalah ini, kelompok pembicara mengadakan administrasi wilayah lokal di MAN sekolah Kisaran. Kekhawatiran ini mendorong kelompok guru untuk melakukan administrasi wilayah dengan membantu sekolah, khususnya MAN Kisaran dengan tujuan agar permasalahan fasilitas penelitian PC di sekolah tersebut dapat 
diselesaikan dengan baik. Ketika pembeli sudah memiliki PC yang sesuai dengan kebutuhannya, masalah yang sering muncul adalah masalah eksekusi dalam pemrograman, misalnya PC sering lemot, PC terkena infeksi, dll (Lubis dan Sembiring, 2018).

Arsitek dan peneliti PC benar-benar memahami sistem kerja dari atas sistem kerja untuk PC adalah jiwa bagi manusia. Tanpa kerangka kerja, PC adalah benda mati yang tidak bisa melakukan apa-apa. Kerangka kerja memainkan bagian penting (Josi, 2019). Dampak signifikan pada PC dan industri korespondensi, mulai dari perakitan PC hingga kombinasi kerangka kerja. Kemajuan kerangka kerja terkoordinasi yang dapat berinteraksi dan mengomunikasikan berbagai jenis informasi dan data. Dapat dibuktikan bahwa kerangka kerja memainkan banyak peran dan kapasitas, karena rencana melibatkan PC dalam kehidupan seharihari (Mair, 2018)..

Kerangka kerja dalam sebuah PC sangat penting mengingat kapasitas kerangka kerja adalah untuk mengontrol semua peralatan pada PC (Haryanto, 2012). Masih banyak kerangka kerja yang digunakan di sekolah-sekolah yang telah disegarkan ${ }_{3}$ kembali oleh masyarakat miskin, masih tertinggal jauh dengan kemajuan-kemajuan perbaikan saat ini. Jelas dari sekolah bahwa masih ada PC yang menggunakan Windows XP, dan Windows 7. Berdasarkan isu-isu yang dijelaskan di atas, persiapan lokal ini selesai untuk survei dan memberikan dalam pembentukan kerangka kerja Windows 10. Tujuan dari bantuan ini adalah siswa MAN Kisaran, dan Jangkauan Pendidik MAN.

\section{STRATEGI}

\section{2}

Dalam penelitian ini dilakukan 4 (empat) tahapan eksplorasi yang telah diselesaikan adalah:

1. Langsung (Persepsi) Pencipta melakukan pemeriksaan dan mengumpulkan informasi melalui pencarian informasi dari sumber yang ada, misalnya responden dengan kerangka kerja windows, perpustakaan dan web.

2. Bicara dengan (Meeting) Untul 2 menyelesaikan informasi yang diperlukan, pencipta memimpin pertanyaan dan jawaban langsung dengan klien dari mahasiswa dan masyarakat umum.

3. Poll (Survey) Penulis memberikan lembar survey kepada responden yang menggunakan PC atau workstation dengan sistem operasi Windows untuk berbagai kalangan, seperti pelajar dan masyarakat umum.. 
4. Library Review Penulisan review dilakukan dengan mencari bahan dari tulisan atau contoh kasus perbandingan di per 2 ustakaan Sekolah Data dan PC Nusa Mandiri Para pelaksana (STMIK), web dan lain-lain yang berhubungan dengan masalah yang akan diteliti.

\section{SPEKULASI}

Hubungan antara faktor-faktor dalam ulasan ini memiliki spekulasi yang menyertainya: :

H0: tidak ada dampak pasti dari detail dalam menzentukan tampilan, akomodasi, kecepatan, proyek yang layak, keamanan kerangka kerja, biaya atau biaya, elemen dan ukuran memori yang digunakan oleh kerangka kerja Windows.

H1: ada dampak positif dari penentuan dalam men ${ }_{2}$ tukan tampilan, kenyamanan, kecepatan, proyek yang layak, keamanan kerangka kerja, biaya atau biaya, sorotan dan ukuran memori yang digunakan oleh kerangka kerja Windows..

\section{Sistem Operasi}

Kapasitas kerangka kerja seperti sebuah administrasi di suatu negara, dalam arti membuat kondisi PC agar dapat menjalankan program secara akurat. Sebagaimana ditunjukkan oleh Abdul Kadir (2013:164), kerangka kerja merupakan program utama dari proyek-proyek yang terdapat dalam kerangka kerja PC. Kerangka kerja dapat dianggap sebagai program kontrol yang pekerjaannya menjalankan berbagai proyek di PC. Sebuah OS (Sistim Operasi) memperluas mesin dan memberikan programmer cara lebih sederhana untuk bekerja dengan perangkat keras.

\section{Sistem Operasi Window}

Versi pertama Microsoft Windows, yang disebut dengan Windows 1.0, dirilis pada tanggal 20 November 1985. Pada awalnya Windows versi 1.0 ini hendak dinamakan dengan Interface Manager, akan tetapi Rowland Hanson, kepala bagian pemasaran di Microsoft Corporation, meyakinkan para petinggi Microsoft bahwa nama "Windows" akan lebih "memikat" konsumen.

Menurut Dony Ariyus (2010:137) "Windows adalah salah satu software system operasi yang dikeluarkan oleh perusahaan Microsoft Inc. Microsoft Windows adalah software system informasi yang paling popular untuk para pengguna PC. Tampilan Windows yang membuatnya menjadi pilihan utama.

\section{Sistem Operasi Linux}

Sistem Operasi Linux adalah sistem operasi mirip Unix yang dulu dirancang untuk memberikan pengguna PC OS gratis atau tingkat rendah sebanding dengan sistem Unix tradisional dan lebih mahal. 
Kegiatan pengabdian ini dilaksanakan di Sekolah MAN Kisaran dengan metode ceramah, memberikan dasar tentang sistem operasi, dan latihan instalasi sistem operasi yang disertai tanya jawab. Pelakasanaan pengabdian masya-rakat ini dihadiri oleh siswa dan siswi MAN Kisaran yang berjumlah 30 siswa dan siswi serta beberapa guru juga turut serta ikut didalam kegiatan ini. Didalam pengabdian ini, Metode ceramah digunakan untuk menjelaskan tentang instalasi maupun troubleshooting yang sering terjadi pada Komputer, Metode demonstrasi dipakai untuk menunjukkan suatu proses kerja yaitu tahap-tahap mengenalan jenis jenis sistem operasi baik desktop maupun mobile, serta mengetahui apa saja yang dapat mempengaruhi atau contoh kerusakan yang sering terjadi pada komputer. Sementara metode tanya jawab untuk memberi kesempatan para peserta dalam berkonsultasi untuk mengatasi kendala dalam memahami materi yang sudah didapat.

\section{PEMBAHASAN}

Dalam pengelolahan hasil penelitian ini dibuatkan beberapa kriteria yang dianggap paling mempengaruhi dalam pengambilan keputusan untuk menentukan sistem operasi seperti tampilan, kemudahan, kecepatan, compatible program, keamanan system, harga atau biaya, fitur dan ukuran memori yang digunakan. Dan alternative yang digunakan yaitu 3 (tiga) jenis windows yang terdiri dari windows 7 , windows 8 dan windows 10 . Berikut adalah struktur hierarki pemilihan sistem operasi windows.

\section{Matrik Perbandingan Berpasangan}

Hasil dari penyebaran kuesioner kemudian diolah kedalam bentuk maktrik perbandingan berpasangan untuk mendapatkan nilai dari masing-masing kriteria yang ada. Berikut ini hasil dari pengolahan data kuesioner yang ditampilkan dalam bentuk tabel sederhana.

Keterangan tabel:

TP : Tampilan

KM : Kemudahan

KC : Kecepatan

CP : Compatible Program

KS : Keamanan Sistem

HG : Harga

FT : Fitur 
UM : Ukuran Memori

\section{Menentukan Eigen Vektor}

Cara mencari Eigen Vektor yaitu dengan menormalisasikan kriteria utama dengan total dari masing-masing kriteria tersebut, kemudian mencari rata-rata tiap kriteria dan menjumlahkan semua rata-rata kriteria itu.

Berdasarkan dari hasil eigen vector diatas dapat ditarik kesimpulan bahwa:

a. Kriteria Keamanan Sistem memiliki posisi tertinggi dengan bobot nilai sebesar 0,21.

b. Posisi kedua yaitu Ukuran Memori dengan bobot nilai sebesar 0,17.

c. Posisi ketiga yaitu Compatible Program dengan bobot nilai sebesar 0,15.

d. Posisi keempat yaitu Fitur dengan bobot nilai sebesar 0,14.

e. Posisi kelima yaitu Kecepatan dengan bobot nilai sebesar 0,12 .

f. Posisi keenam yaitu Kemudahan dan Harga yang memiliki bobot nilai yang sama sebesar 0,08 .

g. Pada posisi terendah yaitu Tampilan dengan bobot nilai sebesar 0,05 .

Sehingga urutan pemilihan sistem operasi windows berdasarkan kriteria utama, sebagai berikut :

1) Keamanan Sistem

2) Ukuran Memori

3) Compatible Program

4) Fitur

5) Kecepatan

6) Kemudahan dan Harga

7) Tampilan

\section{Mengukur Konsistensi Logis}

Mengukur konsistensi dalam pembuatan keputusan perlu dilakukan karena dalam pengambilan keputusan haruslah dengan konsistensi pertimbangan yang baik. Tidak mungkin kita menggunakan konsistensi yang rendah dalam pengambilan keputusan. Berikut cara mengukur konsistensi .

sedang dilakukan, compatible program terhadap aplikasi-apikasi pendukung lainnya, keamanan sistem dari virus-virus yang ada, harga atau biaya untuk memperoleh windows tersebut, fitur yang terdapat didalamnya dan ukuran memori yang digunakan sistem operasi 
windows; dan 4) dalam merancang sistem pendukung keputusan dengan metode Analytical Hierarchy Process haruslah mengikuti tahapan-tahapan yang sesuai dengan metode dan perhitungan yang teliti agar data yang dihasilkan dapat diterima dan keputusan yang dihasilkan dapat diandalkan.

Di dalam penelitian ini, penulis telah mencari jurnal yang membahas tentang perbandingan dari Sistem Operasi Windows dengan Sistem Operasi Linux. Hasilnya hanya didapatkan tiga jurnal yang membahas perbandingan antara Sistem Operasi Windows dan Sistem Operasi Linux.

\section{Instalasi Komputer}

Instalasi adalah pemasangan perangkat lunak pada sistem komputer, Sedangkan instalasi sistem operasi adalah pemasangan sistem operasi pada komputer, Sistem operasi akan dipasang terlebih dahulu dibanding perangkat lunak yang lain, Komputer canggih memerlukan sistem operasi yang juga memang sesuai. Salah satu sistem operasi memungkinkan untuk digunakan saat ini adalah windows 10 (Tutang, 2016).

Masing-masing sistem operasi memiliki ciri tersendiri, Demikian dengan proses instalasi sistem operasi, Proses instalasi sangat bergantung pada jenis sistem operasinya, Berdasarkan tampilan antar mukanya kita dapat membagi menjadi dua, yaitu yang berbasis GUI dan berbasis CLI. (Jubilee, 2019).

Proses Instalasi berbasis GUI pada sistem operasi Microsoft Windows (GUI penuh pada versi Vista), Apple Mac OS ver X dan yang diatasnya, Beberapa versi linux seperti, Ubuntu dan turunannya (Xubuntu, Kubuntu, Edubuntu), Mandriva dan turunannya (PC Linux OS), dan Fedora versi terbaru, Sedangkan versi CLI pada linux versi Slackware, Gentoo dan lain-lain. kehidupan (Mair, 2018).

Proses Instalasi juga dapat dibagi berdasarkan sumber instalasinya, yaitu bersumber dari media baik itu CD, DVD atau hard-disc ATAU usb Drive dan yang bersumber dari network atau jaringan, Pada pengabdian masyarakat ini proses instalasi yang digunakan dengan USB drive.

\section{Setting BIOS}

Bios Merupakan singkatan dari Basic Input Output System merupakan suatu software yang ditulis dalam Bahasa assembly yang mengatur fungsi dasar dari perangkat keras atau hardware. (H. Irsyad, Windows 10 Under Cover Langkah Mudah Menguasai Windows 10, Jakarta: Deepublish, 2016).

Langkah masuk Bios

1. Hidupkan Komputer.

2. Tekan tombol Delete / F2 berulang kali pada saat booting. 


\section{Muncul menu utama BIOS}

Fungsi dan tampilan Bios meliputi:

1. Main Menu (Menampilkan Pengatutan Tanggal, Jam dan informasi drive dan informasi memory.

2. Boot (Menampilkan Setingan pembacaan awal ketika komputer dinyalakan, disini didalam penginstalan komputer harus memilih media penginstalan seperti DVD atau USB pada first drivenya, sedangkan second drive pilih HDD ataupun Hardisk).

3. Exit (Menampilkan informasi save change dan keluar dari Bios)

Langkah - langkah penginstalan sistem operasi windows 10

1. Setelah Bios disetting komputer akan restart.

2. Kemudian akan tampil gambar seperti dibawah ini, Tekan Enter :

3. Pilih Language dan time format

4. Selanjutnya pilih Install now untuk melanjutkan proses instalasi

5. Jika sudah maka akan tampil informasi license windows, pilih accept kemudian next

6. Selanjutnnya kita akan memilih tipe dalam penginstalan, kemudian pilih costum .

7. Pembagian partisi

8. Pada menu pembagian partisi, buat 2 partisi yaitu yang pertama Drive $\mathrm{C}$ dan yang kedua Drive $\mathrm{D}$, kapasitas kedua drive tergantung kebutuhan masing-masing.

9. Kemudian setelah kita selesai melakukan atau membuat partisi kemudian pilih next untuk melanjutkan proses instalasi.

10. Setelah loading selesai, komputer akan restart kemudian akan muncul tampilan awal sistem operasi windows 10 seperti gambar dibawah ini:

11. Setelah penginstalan sistem operasi selesai, tinggal menginstal software yang dibutuhkan dan juga driver jika diminta untuk dilakukan penginstalan driver.

Berikut ini dokumentasi kegiatan pengabdian kepada masyarakat dengan tema Instalasi sistem operasi berbasis windows 10 Pada MAN Kisaran dengan penyampaian materi dari awal pembaha san dasar instalasi sistem operasi windows 10 .

\section{KESIMPULAN}

Berdasarkan hasil dari analisa dan pengolahan data pada pembahasan sebelumnya yang telah dilakukan oleh penulis, dapat ditarik kesimpulan sebagai berikut: 1) metode Analytical Hierarchy Process dapat digunakan untuk sistem pendukung keputusan pemilihan sistem operasi 
windows, dengan menentukan tujuan, kriteria dan alternatif yang akan digunakan dengan membentuk sebuah hierarki, sehingga dapat membantu dalam melihat permasalahan yang dihadapi secara lebih terperinci; 2) alternatif yang digunakan yaitu sistem operasi yang sering digunakan saat ini dan sistem operasi windows yang terbaru seperti windows 7 , windows 8 dan windows 10. Dari hasil pembahasan bahwa windows 10-lah yang paling diminati responden dengan presentasi sebesar 38\% ditempat kedua yaitu windows 7 sebesar 34\%. Walaupun termasuk kedalam windows keluaran lama namun masih banyak reponden yang menyukai windows 7 tentunya dengan beberapa pertimbangan. Pada posisi terakhir yaitu windows 8 dengan presentasi $28 \%$. Dari hasil tersebut dapat menjadi pertimbangan dalam menentukan sistem operasi windows yang akan digunakan; 3) banyak hal yang menjadi pertimbangan seseorang untuk memilih sistem operasi windows apa yang akan digunakan, tetapi dari banyak pertimbangan yang ada faktor yang sering menjadi pertimbangan seperti tampilan dari windows tersebut, kemudahan dalam pengoperasiannya, kecepatan waktu yang diperlukan saat proses sedang dilakukan, compatible program terhadap aplikasi-apikasi pendukung lainnya, keamanan sistem dari virus-virus yang ada, harga atau biaya untuk memperoleh windows tersebut, fitur yang terdapat didalamnya dan ukuran memori yang digunakan sistem operasi windows; dan 4) dalam merancang sistem pendukung keputusan dengan metode Analytical Hierarchy Process haruslah mengikuti tahapan-tahapan yang sesuai dengan metode dan perhitungan yang teliti agar data yang dihasilkan dapat diterima dan keputusan yang dihasilkan dapat diandalkan.

Simpulan yang dapat diambil dari kegiatan pengabdian masyarakat ini, Siswa-siswi MAN kisaran dan juga guru sekolan MAN kisaran dapat mengenal serta mengatasi permasalahan yang sering terjadi pada sistem operasi windows, Serta memahami perkembangan sistem operasi pada komputer. Dengan memberikan materi praktek langsung serta memberikan tutorial penginstalan sistem operasi lebih memudahkan bagi siswa dan siswi dalam melakukan instalasi langsung disekolah maupun dirumah.

\section{DAFTAR PUSTAKA}

Eska, J., Afrisawati, A., \& Ihsan, M. (2018). PELATIHAN INSTALASI SISTEM OPERASI WINDOWS PADA PERSONAL COMPUTER. JURDIMAS ROYAL, 1(2), 23-32.

Haryanto, EV ., Sistem Operasi Konsep \& Teori, Yogyakarta: Deepublish, 2012.

Irsyad, H., Windows 10 Undercover Langkah Mudah Menguasai Windows 10, Jakarta: Deepublish, 2016.

Josi, A., Konsep dan Perkembangan Sistem Operasi. Jakarta: Deepublish, 2019.

Jubilee, Lancar menggunakan MS Windows 10 dan MS Office 2019, Jakarta: Deepublish, 2019 
Lubis, J. H., \& Sembiring, Z. (2018). Pelatihan Instalasi Komputer, Cloning Sistem Operasi, Serta Membuat File Sharing Pada Jaringan Komputer. Jurnal Prodiknas Hasil Pengabdian Masyarakat, 2(1), 65-70. jurnal.umsu.ac.id/index.php/prodik mas/article/download/1766/pdf_13.

Mair,ZR., Teori dan Peraktek Sistem Operasi. Yogyakarta: Deepublish, 2018.

Tutang, Step by step microsoft windows 10, Bekasi: Deepublish, 2016.

Abilash, P \& Abinay Sri vastav V. (2015). Comparison of Windows and Linux Operating Systems inAdvanced Features, Journal of Engineering Reaseach and aplications, vol 5 issue 2 Part 3.

Anthu Priya Rani. P dan Rohini V. (2017). Performance Evaluation of Recent Windows Operating Systems, International Journal of Innovative Reasearch in Advaced Engineering (IJIRAE), issue $03 \mathrm{Vol} 4$.

Irianto, Jelang Fajar. (2018). Perkembangan Sistem Operasi Windows, It Sharing for Indonesia Open Knowledge (ILMUTI).

Nelfira dan Diana Silvia. (tahun) Rancang Bangun Aplikasi Pembelajaran Sistem Operasi Windows Pada Matakuliah Sistim Operasi di STMIK Indonesia Padang Berbasis Multimedia Interaktif.”, Jurnal Edik Informatika V2i2.

Sirait, Parulian \& R. Fanry Siahaan. (2019). Analisis Kinerja Windows Server dan Linux Server Terhadap Respons Time Squid Proxy, Journal of Informatic Pelita Nusantara, Volume 4 No. 2

Watriantos, R \& I Purnama. (2018). Buku Ajar Sistem Operasi. Ponorogo: Uwais Inspirasi Indonesia

Fuspita, V., Vatresia, A., \& Andreswari, D. (2015). Sistem Pendukung Keputusan Pemilihan Restoran di Kota Bengkulu Dengan Metode Simple Additive Weighting (SAW) Berbasis Sistem Operasi Android. Rekursif: Jurnal Informatika, 2(1). Retrieved from https://ejournal.unib.ac.id/index.php/rekur sif/article/view/305

http://ejournal.gunadarma.ac.id/index.php/ infokom/article/view/1094/955

Kusnadi, Anindito, K., \& Purnomo, S. (2009). Sistem Operasi (1st ed.). Yogyakarta: Andi Publisher. Retrieved from http://andipublisher.com/produk0902002881-sistem-operasi.html

Madcom. (2010). anduan Lengkap Microsoft Windows 7 (1st ed.). Yogyakarta: Andi Publisher. Retrieved from $\underline{\text { http://andipublisher.com/produk1007003469-panduan-lengkap- }}$ microsoftwindows-7.html

Sabiq, A. (2013). Metode Fuzzy AHP Dan Fuzzy Topsis Untuk Pemilihan Distro Linux. Orbith, 9(2), 78-83. Retrieved from https://www.researchgate.net/profile/Ahm 
ad_Sabiq/publication/302586555_METODE

FUZZY AHP DAN FUZZY TOPSIS UNTUK P

EMILIHAN_DISTRO_LINUX/links/5731a929 08ae100ae55822ec.pdf

Wahana Komputer. (2013). Quick Reference Windows 8 (1st ed.). Yogyakarta: Andi Publisher.

Retrieved from http://andipublisher.com/produk0113004604-quick-reference-windows 8 .html

Susilo, D. (2016). Prototipe Sistem Pendukung Keputusan Untuk Membandingkan Sistem Operasi Terbaik Pada Ponsel Menggunakan Metode TOPSIS. Ponorogo. Retrieved from http://eprints umpo.ac.id/2338/1/HALAMA N DEPAN.pdf 
ARTIKEL_ALI_NAFIA_NASUTION_SI-6.docx

ORIGINALITY REPORT

$18 \%$

SIMILARITY INDEX
$18 \%$

INTERNET SOURCES
$1 \%$

PUBLICATIONS
$2 \%$

STUDENT PAPERS

PRIMARY SOURCES

1 universitassuryadarma.ac.id

Internet Source

2 www.neliti.com

Internet Source

3 jurnal.stmikroyal.ac.id

4 nisasekedarshare.blogspot.com

Internet Source

5 ejournal.uin-suska.ac.id

Internet Source

6 teknowil.blogspot.com

Internet Source

7 bloganakkomputer.blogspot.com 
Exclude bibliography On 